\title{
Çelik-Beton Kompozit Kat Döșemesi Yangın Dayanım Deneyi
}

\author{
Serdar SELAMET ${ }^{1}$ \\ Taygun Furat YOLAÇAN ${ }^{2}$
}

\section{ÖZ}

Bu çalışma kapsamında Türkiye'de araştırma odaklı ilk çelik-beton kompozit kat döşemesi yapısal yangın deneyi gerçekleştirilmiştir. $\mathrm{Bu}$ çalışma, Türkiye'de gerek yangın yönetmelikleri açısından gerekse yapısal yangın konusunda teorik, nümerik ve deneysel araştırmalardaki eksiklikleri gidermeyi amaçlamaktadır. Yüksek katlı çelik bir yapı için tasarlanmış kompozit döşemenin iki kenarında simetrik bir birleşim mekanizması kullanılmış ve bu şekilde yangın firını alanından daha büyük bir döşeme alanı testi imkânı sağlanmıştır. Yangın firınına monte edildikten sonra döşemenin alt yüzeyi ISO834 standart yangın eğrisiyle 105 dakika isıtılmış ve sonrasında 90 dakika kontrollü olarak soğutulmuştur. Deney sırasında yapının sehim ve sıcaklık ölçümleri yapılmıştır. Alınan sonuçlar, beton döşemenin membran davranışı göstererek yük taşıyıcı özelliğini yangın boyunca devam ettirdiğini göstermektedir. Dolayısıyla kompozit kat döşemelerinde ikincil çelik kirişlerin yalıtımsız kalması önerilmektedir.

Anahtar Kelimeler: Yangın dayanımı testi, simetrik birleşim mekanizması, yapısal yangın mühendisliği, kompozit döşeme, çelik bağlantı.

\begin{abstract}
\section{Fire Resistence Testing of a Steel-Concrete Flor Slab}

This study conducts the first research based structural fire resistance test on a steel-concrete composite floor in Turkey. The goal of this research is to fill the knowledge gaps in the current Turkish building code for the structural fire safety and provide valuable insight for the development of new theoretical, computational and experimental research. The tested composite floor is specifically designed for a high-rise steel building. The floor is equipped with a patent pending mechanism to provide symmetric boundary conditions on two edges. The floor is subjected to ISO-834 standard fire curve from the bottom surface for 105 minutes followed by 90 minutes cooling. Displacement and temperature measurements show that at elevated temperatures, the concrete slab carries the load by tensile membrane action without contribution of the secondary beams. This study suggests that secondary
\end{abstract}

\footnotetext{
Not: Bu yaz1

- Yayın Kurulu'na 01.03.2016 günü ulaşmıştır.

- 30 Eylül 2017 gününe kadar tartışmaya açıktır.

- DOI: $10.18400 /$ tekderg.307544

1 Boğaziçi Üniversitesi, İnşaat Mühendisliği Bölümü, İstanbul - serdar.selamet@boun.edu.tr

2 Boğaziçi Üniversitesi, İnşaat Mühendisliği Bölümü, İstanbul - firat.yolacan@boun.edu.tr
} 
Çelik-Beton Kompozit Kat Dössemesi Yangın Dayanım Deneyi

steel beams are not need for fire protected as the concrete slab is sufficient in carrying gravity loading.

Keywords: Fire resistance test, symmetric connection mechanism, structural fire engineering, composite floor, steel connection.

\section{GİRiş}

Bu çalışmada, yüksek katlı yapılarda sıklıkla kullanılmakta olan birincil kirişler, ikincil kirişler, beton döşeme ve çelik bağlantılardan oluşan ve literatürde halen yangın esnasında oluşan yüksek sıcaklıklar altında davranışı analitik yöntemlerle açıklanamamış olan kompozit döşeme sistemlerinin, yangın esnasında oluşan yüksek sıcaklıklar altında dayanım ve davranışının deneysel yöntemlerle ölçülmesi hedeflenmektedir. Yangın dayanım deneyi dışında, patent başvurusu gerçekleştirilmiş olan düşeyde serbest ve moment aktaran yeni birleşim mekanizması tasarlanmıştır. Yangın testlerinde kullanılan firınların sınırlı boyutlarda olması nedeniyle yangın testleri için uygun olmayan ölçülerdeki döşeme sistemlerinin simetrik parçalar halinde test edilmesine olanak sağlayacak bir mekanizma yangın dayanım deneyi ile test edilecektir.

Gerçek boyutlarda kompozit döşemenin $(8.6 \mathrm{~m}$ x $7.6 \mathrm{~m})$ sadece çeyreği yukarıda bahsi geçen birleşim mekanizması kullanılarak ISO834 standart yangın eğrisine maruz bırakılacak ve sonrasında kontrollü olarak soğutulacaktır. ISO834 standart yangını ve kontrollü soğuma esnasında kompozit döşemeye ait sehim ve sıcaklık değerleri kaydedilecektir ve döşemenin yangın performansı irdelenecektir.

Son yıllarda gerçekleştirilen betonarme döşeme sistemlere ait yangın deneyleri, bu bölmelerin çökmeye karşı dirençli olduğunu göstermiştir [3, 4]. Bunun nedeni, beton döşemenin çevresel kirişler ve kolonlar tarafından desteklenip bir 'membran' gibi davranmasıdır. $\mathrm{Bu}$ davranış için yaklaşık bir analitik çözüm bulunmuştur $[5,6,7]$, ayrıca deney sırasında gözlemler çöküş mekanizması hakkında bilgi vermiştir $[8,9]$. Beton döşemenin, çekme kuvvetlerine karşı membran mekanizması ile yangına karşı daha dirençli olduğu bilinmesine rağmen, çelik kesme bağlantılarının bu çeşit bir sistemde dönme ve çekme kuvvetine maruz kalıp kalmayacağı tartışılan bir konudur [10, 11, 12]. Çelik bağlantılar, yapıların sabit kalması, özellikle kolonların yatay desteklenmesi ve burkulma yaşamaması için önemli bir fonksiyona sahiptir $[1,13,14]$. Bu nedenle yangından kaynaklanan kuvvetlere karşı yetersiz bağlantı gerilimi veya yetersiz süneklik durumu, çelik yapıda çökmeye yol açabilir. Kompozit döşemenin yangın altındaki yüksek sehimi ancak çelik bağlantıların dönme kapasitelerinin yükseltilmesi ve daha sünek şekilde tasarlanması ile olur $[15,16,17]$. Bununla beraber bulonların yangına karşı dayanıklılığı diğer çelik malzemelerine karşı değişiklik göstermektedir ve çelik bağlantılarının mekanik davranışlarını tespit etmeyi daha da zorlaştırmaktadır [18].

Yukarıda verilen literatür bilgisi ışığında bu projenin literatüre yapacağı katkı aşağıda belirtilmiştir:

Geçmişte yapılan deneylerde anlaşıldığ 1 üzere, sadece beton döşemenin yangına karşı performansı analiz edilmiştir. Çelik kiriş ve bağlantılardan oluşan kompozit sistemin yangın dayanım deneyi bu alana yenilik getirecektir. Bu deney ile birlikte simetrik koşulları sağlayan yeni bir birleşim mekanizması hem oda hem de yüksek sıcaklıklarda test edilmiştir. 


\section{YANGIN DAYANIM TESTI}

Boyutları 8.6 m x 7.6 m olan yüksek katlı bir bina döşeme sisteminin simetrik çeyreği Şekil 1 'de gösterilmiştir. Döşeme sistemi; birincil kirişler, ikincil kiriş, beton döşeme ve çelik bağlantılardan oluşmakta ve kompozit döşemenin $4.3 \mathrm{~m}$ x $3.8 \mathrm{~m}$ boyutlarındaki simetrik çeyreğini temsil etmektedir. Döşeme betonu, Eurocode standartlarına uygun olarak 4 ay bekletilmiş ve nem oranı 2.6\% olması koşuluyla test edilmek için hazırlanmıştır. Deney Efectis Era Avrasya Yangın Laboratuvarı'nda gerçekleştirilmiştir. Binaların Yangından Korunması Hakkında Yönetmelik'te, döşemeler ile birlikte 30,50m'den yüksek binalardaki tüm yapı elemanlarında $120 \mathrm{dk}$ standart yangın eğrisine (IS0834) dayanım aranmaktadır [19]. Ancak bu kapsamda çelik kirişlerin yalıtıldı̆̆ 1 varsayılmaktadır. Yangın dayanım testinde ikincil çelik kiriş yalıtılmadığ 1 için daha ihtiyatlı davranılıp döşeme alt yüzeyinden sadece 105 dakika ISO834 standart yangın eğrisine maruz bırakılmış ve ardından 90 dakika kontrollü olarak soğutulmuştur.

1-Birincil kirişler 2-Yangın firını 3-İkincil kiriş 4-Beton döşeme

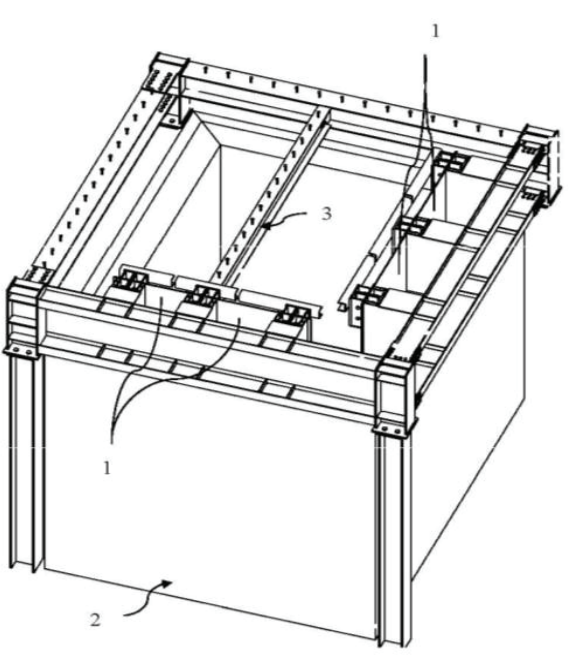

(a)

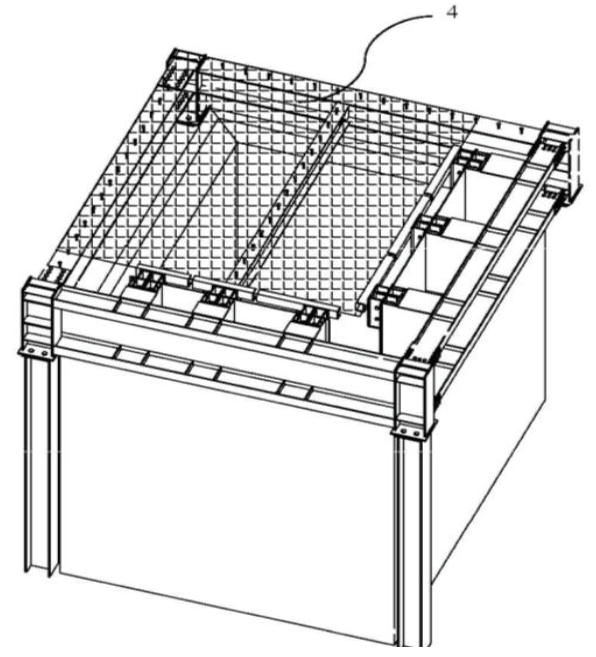

(b)

Şekil 1. 4.3 m x 3.8 m büyüklügüundeki çelik-beton kompozit döşeme ve çelik çerçevesinin yangın firınına monte edilmiş halindeki CAD çizimleri (a) beton döşeme olmadan, (b) beton döşeme ile.

\subsection{Test Düzeneği}

Birincil kirişler, ikincil kiriş, beton döşeme ve çelik bağlantılardan oluşan kompozit döşeme sistemine ait elemanlar Şekil 1 ve 2'de numaralandırılarak ilgili şekiller üzerinde belirtilmişlerdir. Şekil 1b'de görülen çelik-beton kompozit döşeme sisteminin iki kenarında yer alan birincil kirişler için HEA 400 kullanılmış ve bu kirişler birbirlerine ankastre olarak bağlanmıştır. Döşemenin diğer iki kenarı ise simetrik eksenlerdir ve Şekil 3 ve 4'de gösterimi yapılan simetrik sınır koşulları sağlayan birleşim mekanizması ile diğer ana 
Çelik-Beton Kompozit Kat Döşemesi Yangın Dayanım Deneyi

kirişlere bağlanmıştır. Toplamda dört ana kiriş yangın firını duvarları üzerine oturtulmuş ve beton kayma kamaları ('shear stud') ile çelik çerçeveye bağlanmıştır. Deneyde kullanılan döşemede yüksek katlı yapılarda sıklıkla kullanılan C30 tipi beton kullanılmıştır. Beton kalınlığ $10-120 \mathrm{~mm}$ arasında değişen bir sac trapez ile belirlenmiştir. S500 A252 tipi çelik hasır donatı betonun üst yüzeyinden $50 \mathrm{~mm}$ uzaklıkta olacak şekilde betonun içine yerleştirilmiş̧ir. Dössemenin ortasında (ve altında) bir ikincil kiriş (IPE330) bulunmaktadır. $\mathrm{Bu}$ kiriş, Şekil 3'de gösterilmiş olan kesme bağlantısı ile birincil kirişe (HEA 400) bağlanmıştır. Kompozit döşemeye ait çelik çerçeve, yangın laboratuvarına getirildikten sonra üzerine $\mathrm{C} 30$ beton dökülmüş ve oluşturulan çelik-beton kompozit döşeme yangın testi şartlarına uygun olacak şekilde nem yüzdesinin azalması için test öncesinde 4 ay süre ile bekletilmiştir. Oluşturulan kompozit döşeme, beton olmadan yaklaşık olarak 11 ton, beton ile ise 14 ton ağırlığındadır.

Kompozit döşeme sistemi, yangın firınına yatay olarak monte edilmiştir. Monte işleminde ana kirişler yangın duvarlarına oturtularak çelik bulonlar ve kaynaklama ile sabitlenmiştir. Döşemenin tüm alanı, IPE 330 ikincil kirişi ve çelik kesme bağlantısı fırının içinde kalmıştır ve yangına direkt maruz bırakılmıştır. HEA 400 birincil kirişleri ve simetrik koşulları sağlayan ana kirişler (toplamda dört adet) firın dışında olup, yangına dolaylı olarak maruz kalmıştır. Fırının içinde kalan simetrik koşullar sağlayan birleşim mekanizması ve kesme (mafsal) bağlantısı dışındaki tüm bölgeler yalıtımsız bırakılmıştır. Simetrik koşullar sağlayan birleşim mekanizması ve bağlantı bölgesi 25 mm'lik 2 adet seramik yünü ile kaplanmış ve yangın testi esnasında ortaya çıkacak olan yüksek sicaklıklara karşı yalıtılmıştır.

1-Birincil kirişler 5-Lineer rulman sistemi 6-C profil 7-Hareketli kiriş 8-Rulman 9-Pim 10-Birinci pim destek yan plaka 11-İkinci pim destek yan plaka 12-Dikey destek plaka 13-Yatay destek plaka 14-Kayma kaması
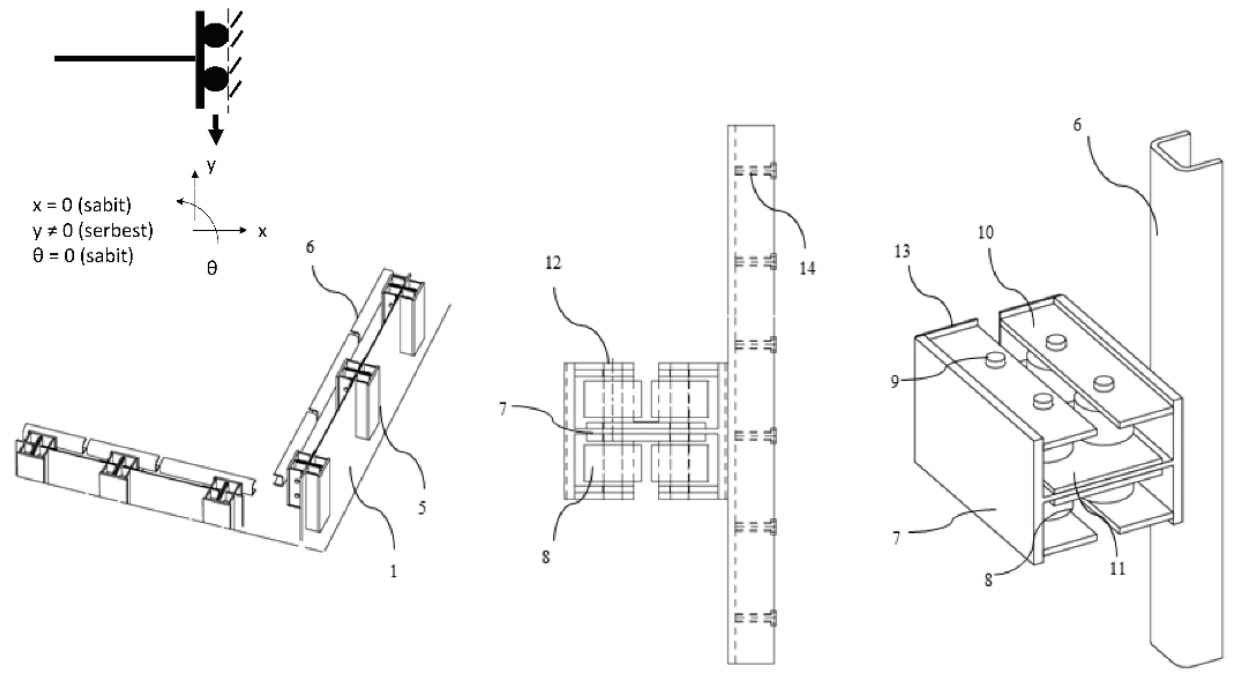

Şekil 2. Simetrik sınır koşullarını săglayan birleşim mekanizması: Moment aktaran, yatay sabit ve dikey serbestlik sağlayan lineer rulman sistemi CAD çizimi. 


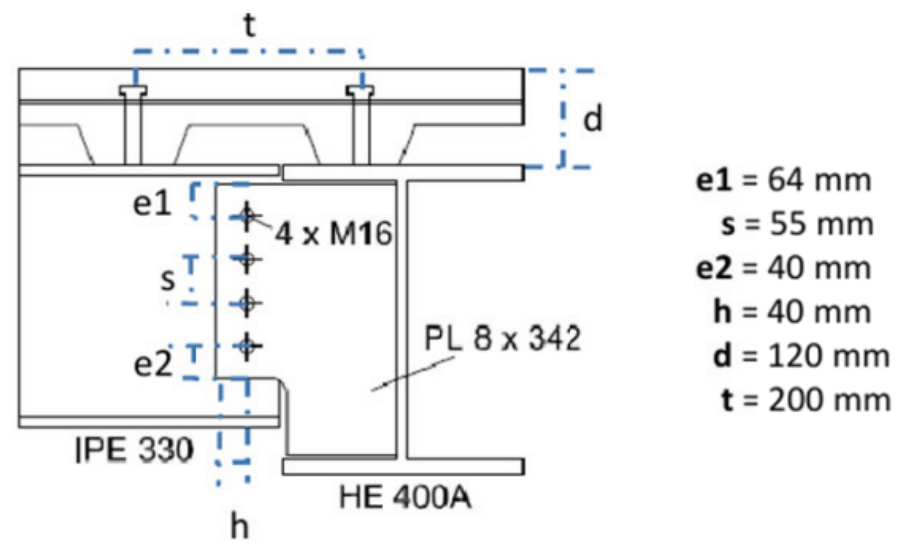

Şekil 3. IPE330 İkincil kiriş - HEA400 Birincil kirişi kesme bağlantı detayl.

\subsection{Simetrik Birleşim Mekanizması}

Yangın davranış testleri genellikle yangın firınlarında gerçekleştirilmektedir. Ancak, döşemelerin de dâhil olduğu büyük genişlikteki yatay yapılara ait yangın davranış testleri kısıtlı hacimlere sahip yangın firınlarında yapılamamaktır. Geniş boyutlu döşemeler ancak ölçekli şekilde imal edilerek test edilmektedir. Ölçeklendirilmiş bir yapının ısı dağı̆lımı ölçeklendirilmemiş yapıdan görece büyük farklılıklar göstermekte ve bu durum dolaylı olarak mekanik davranışa etki etmektedir. Bu nedenle, ölçeklendirilen bir yapının yangın davranış testi sonuçları ile gerçek boyuttaki bir yapı davranış testi sonuçları aynı olmayacaktır.

Sekiz metre genişlikten büyük bir yapıyı test edecek büyüklüğe veya donanıma sahip ulusal veya uluslararası bir yangın firını bulunmamaktadır. Bu nedenle laboratuvar ortamında büyük genişlikteki kompozit döşemeler test edilememektedir.

Bu çalı̧̧ma kapsamında Şekil 2'de şematik ve Şekil 4'de üretimi gerçekleştirilmiş olarak gösterilen moment aktaran, yatay düzlemde sabit hem çekme hem de basınca karşı dayanıklı, düşey düzlemde serbest olan simetrik sınır koşulları sağlayan bir yangın dayanım test mekanizması üretilmiştir. $\mathrm{Bu}$ proje aşamasında ortaya çıkan buluş için Türk Patent Ofisine başvuru yapılmıştır [20].
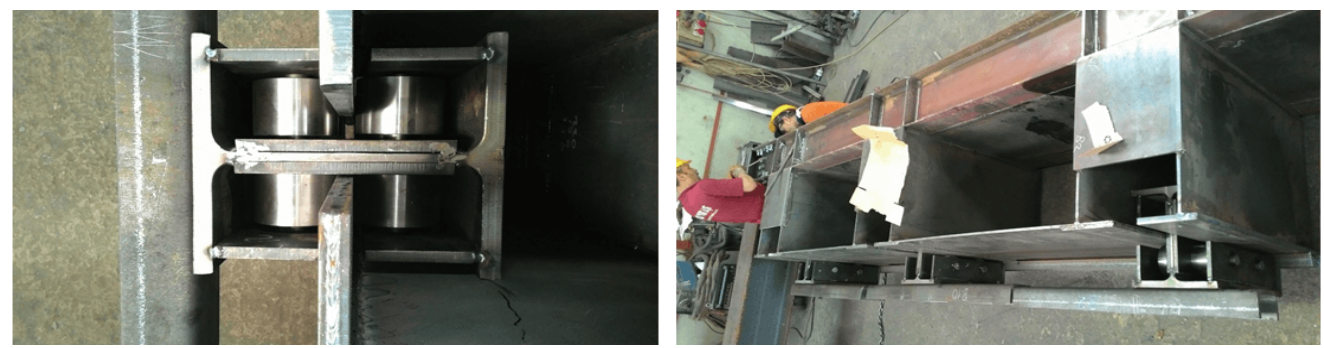

Şekil 4. Simetrik sınır koşullarını sağlayan birleşim mekanizmasının moment aktaran, yatay sabit ve dikey serbestlik sağlayan lineer rulman sistemi. 
Çelik-Beton Kompozit Kat Döşemesi Yangın Dayanım Deneyi

\section{3. Ölçüm Metotları}

Çelik-beton kompozit döşeme, düşey statik yükleme ve yangın testi öncesinde ölçüm aletleri ile donatılmış ve hem yangın öncesi hem de yangın sonrası kontrollü soğuma esnasında kesintisiz olarak izlenmiş̧ir. Isıl-çiftler ile sıcaklık, doğrusal deplasman ölçme cihazları (LVDT) ile de sehim ölçülmüştür.

\subsubsection{Sıcaklık Ölçerler}

Tüm ısıl-çiftler, krom-demir alaşımı 'inconel' malzeme ile kaplı K- tipidir ve $1200{ }^{\circ} \mathrm{C}$ 'ye kadar dayanıklıdırlar. Şekil 5'de yer haritası gösterimi yapılmış olan 1 sıl çiftler ile yangın firını, ikincil kiriş orta bölgesi, ikincil kiriş (IPE 330) - birincil kiriş (HEA 400) bağlantı bölgesi ve donatı üzerinde sıcaklık ölçümleri gerçekleştirilmiştir. Fırın içerisinde bulunan ısıl-çiftler (T4-T11), firının ISO834 yangın eğrisine uygun olarak brülörler tarafından düzgün yayılı olarak 1sıtıldığını teyit etmek için kullanılmıştır. İkincil kiriş (IPE 330) ve birincil kiriş (HEA 400) bağlantısı üzerine 4 adet, ikincil kiriş (IPE330) orta bölgesine 3 adet ve ikincil kiriş simetrik birleşim mekanizması bağlantısı yakınına 3 adet 1sıl-çift yerleştirilmiştir (TC15-TC24). Tüm 1sıl-çiftler çelik yüzeyine yerleştirilmiştir. Kesme bağlantısındaki ısıl-çiftler yalıtım altında kalmıştır. Beton döşeme içindeki A252 çelik hasır üzerine toplamda 12 adet 1sıl-çift yerleştirilmiştir (TC3-TC14).
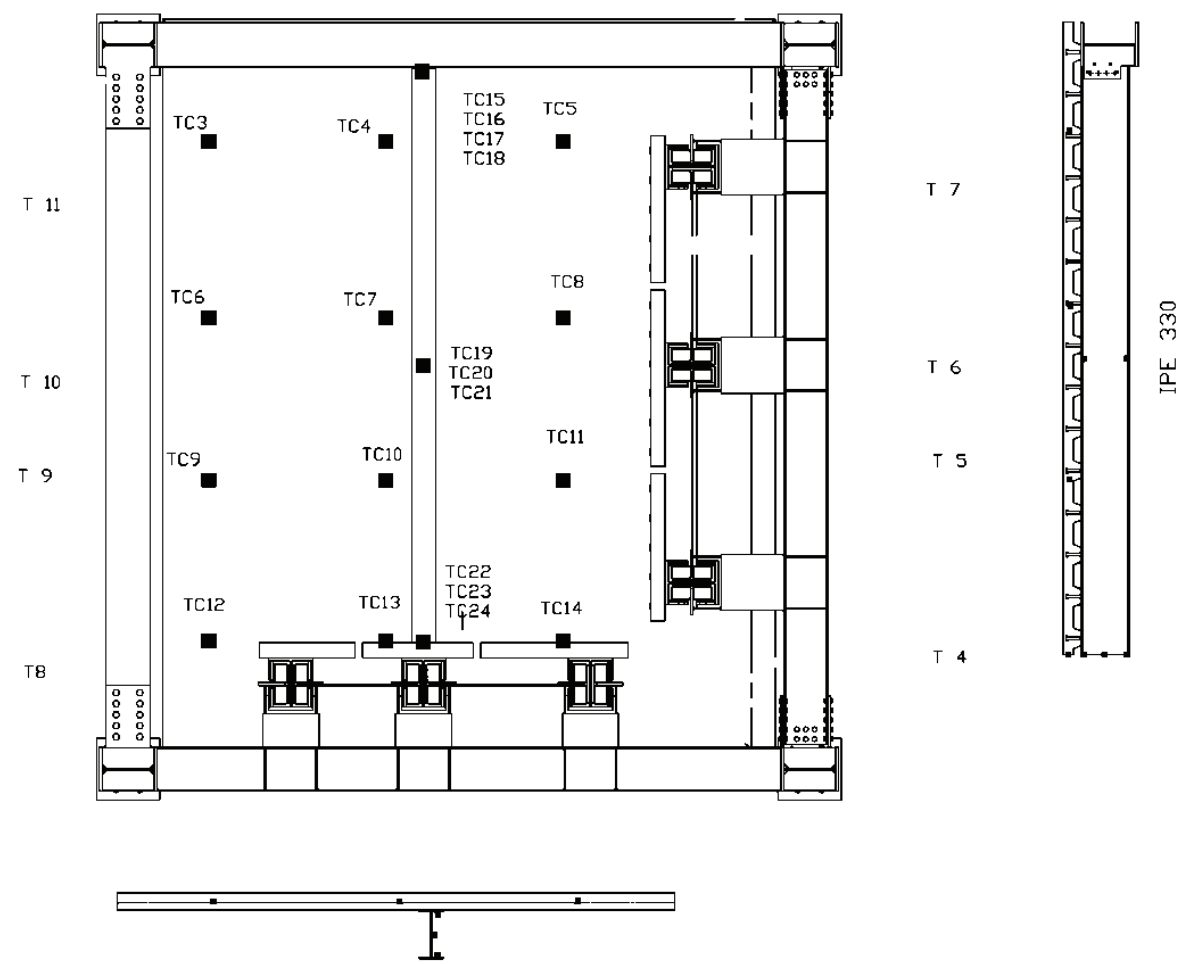

Şekil 5. Furın içindeki ve kompozit döşeme üzerindeki ısıl-çift (TC) ölçerlerin yer haritası. 


\subsubsection{Sehim Ölçerler}

Şekil 6'de yer haritası gösterilmiş olan sehim ölçerler (D1-D12) beton döşemenin membran çekme etkisine girip girmediğini ve bu etkiye ne zaman girdiğini gözlemlemek amaciyla yerleştirilmiştir. Sehim ölçerler beton yüzeyin üzerine yerleştirilmişlerdir. Sehim ölçerler için ısıya dayanıklı ve genleşmeyen bir malzeme kullanılmıştır. Ölçülen sehim ile simetrik birleşim mekanizmasının düşey serbestlik verip vermediği teyit edilmiştir.

\subsection{Düşey Statik Yükleme}

Denklem - 1, Eurocode (EC1) Standardına göre ofis yapıları için yapısal yangın anında uygulanması gereken yük kombinasyonunu göstermektedir. Denklem - 1 de " $w$ " yangın tasarım yükünü, " $Q$ " hareketli yükü, " $G$ " ise yapı sabit yükünü ifade etmektedir [21]. Denklem - 1 de " $Q$ " ile ifade edilen yükleme Eurocode (EC1) Standardına uygun olacak şekilde beton yüzeyine $2.5 \mathrm{kN} / \mathrm{m}^{2}$ düzgün yayılı yük olarak uygulanmıştır [21]. Şekil 7'de düzgün yayılımı gösterilmiş olan " $Q$ " hareketli yükü 10 adet $200 \mathrm{~kg}, 5$ adet $375 \mathrm{~kg}, 13$ adet $20 \mathrm{~kg}$ kullanılarak oluşturulmuştur. Yapı sabit yükü " $G$ ” beton özgül ağırlığı yani yaklaşık $2.4 \mathrm{kN} / \mathrm{m}^{2}$ olacak şekilde dikkate alınmıştır. Bu bilgiler ışığında Denklem - 1'e göre yangın tasarım yükü $3.75 \mathrm{kN} / \mathrm{m}^{2}$ 'dir.

$w=1,0 G+0,5 Q$
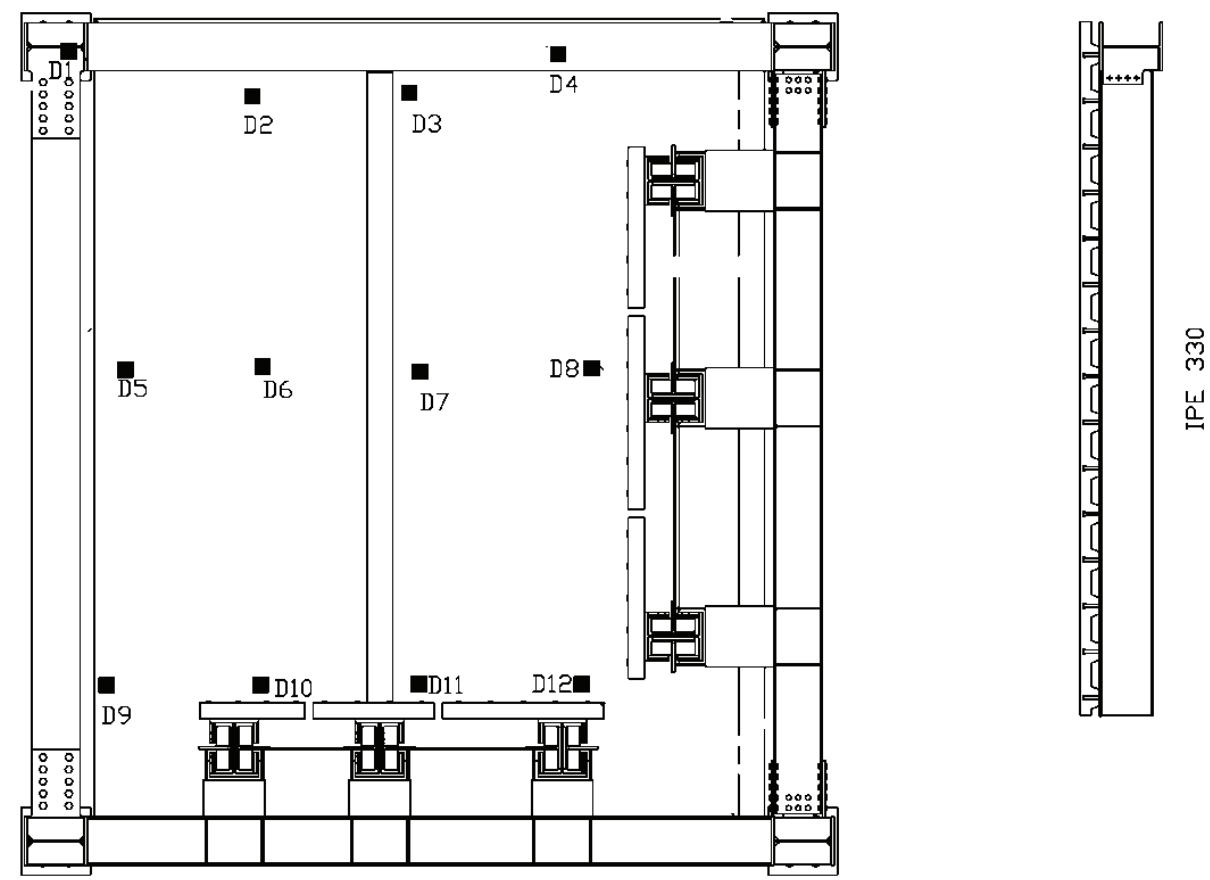

Şekil 6. Kompozit döşseme üstündeki sehim (D1-D12) ölçerlerin yer haritasl. 


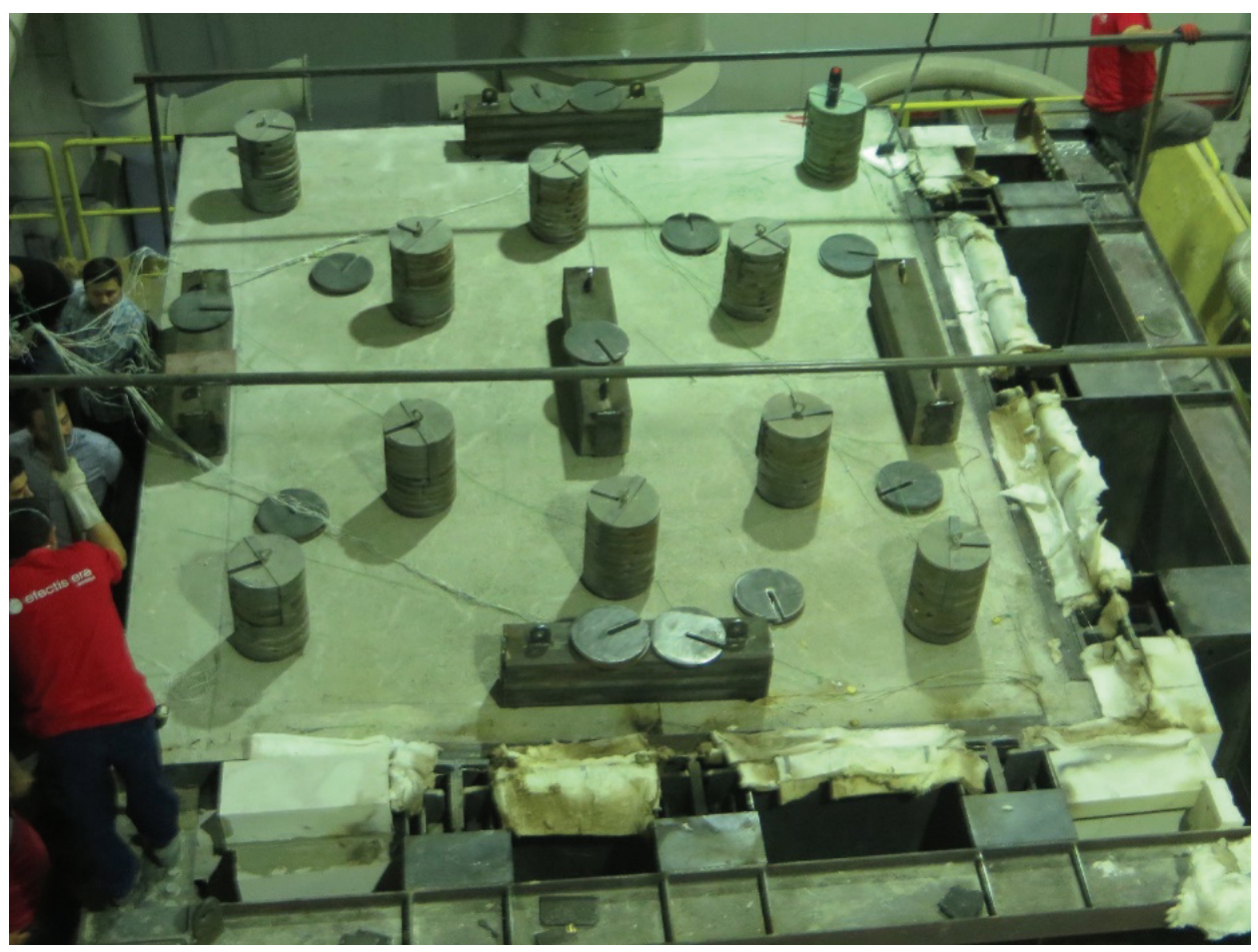

Şekil 7. Kompozit döşeme üzerindeki test öncesinde yükleme durumu.

\section{GÖZLEM VE DEĞERLENDİRMELER}

Yangın firınında ISO834 yangın eğrisine maruz bırakıldıktan 5 dakika sonra kompozit döşemenin simetrik eksenlerinden duman çıkmaya başlamıştır. 20 dakikada döşemede gözle görülür yatay yer değiştirmeler gözlemlenmiştir. 25 dakika içerisinde beton yüzeyinde çatlaklar gözlenmiştir. Bununla birlikte deneyin 30. dakikasından itibaren beton yüzeyinden gözle görülür miktarda su buharı çıkmıştır ve kabarmalar oluşmuştur. Soğuma esnasında ise döşemede az miktarda yukarı doğru geri çekilme olmuştur. Bunun nedeni ikincil kirişin (IPE330) soğuyarak mukavemetini ve rijitliğini geri kazanması olarak yorumlanabilir.

\subsection{Firın Sicaklıkları}

Fırındaki ortam sıcaklığı, fırın hacminin ortasına yerleştirilen isıl-çiftler ile ölçülmüştür. Fırın içerisine yerleştirilen ısıl-çiftlerin yer haritası Şekil 5'de gösterilmiştir (T4-T11). Yangın firını, firın içerisindeki sıcaklığı ISO834 sıcaklık eğrisini uygun olacak şekilde oluşturmak için hacimdeki basıncı ve gaz brülörü ayarını otomatik olarak değiştiren dijital bir mekanizma ile donatılmıştır. Bu sayede tüm hacimde tekdüze ve ISO834 eğrisine çok yakın bir sıcaklık eğrisi elde edilmiş̧ir. Şekil 8 yangın firını içerisinde yer alan ısıl çiftlere 
ait sıcaklık eğrileri göstermektedir. 105 dakika 1sınma sonrasında gaz brülörleri kapatılıp 90 dakika kontrollü bir soğuma evresine girilmiştir.

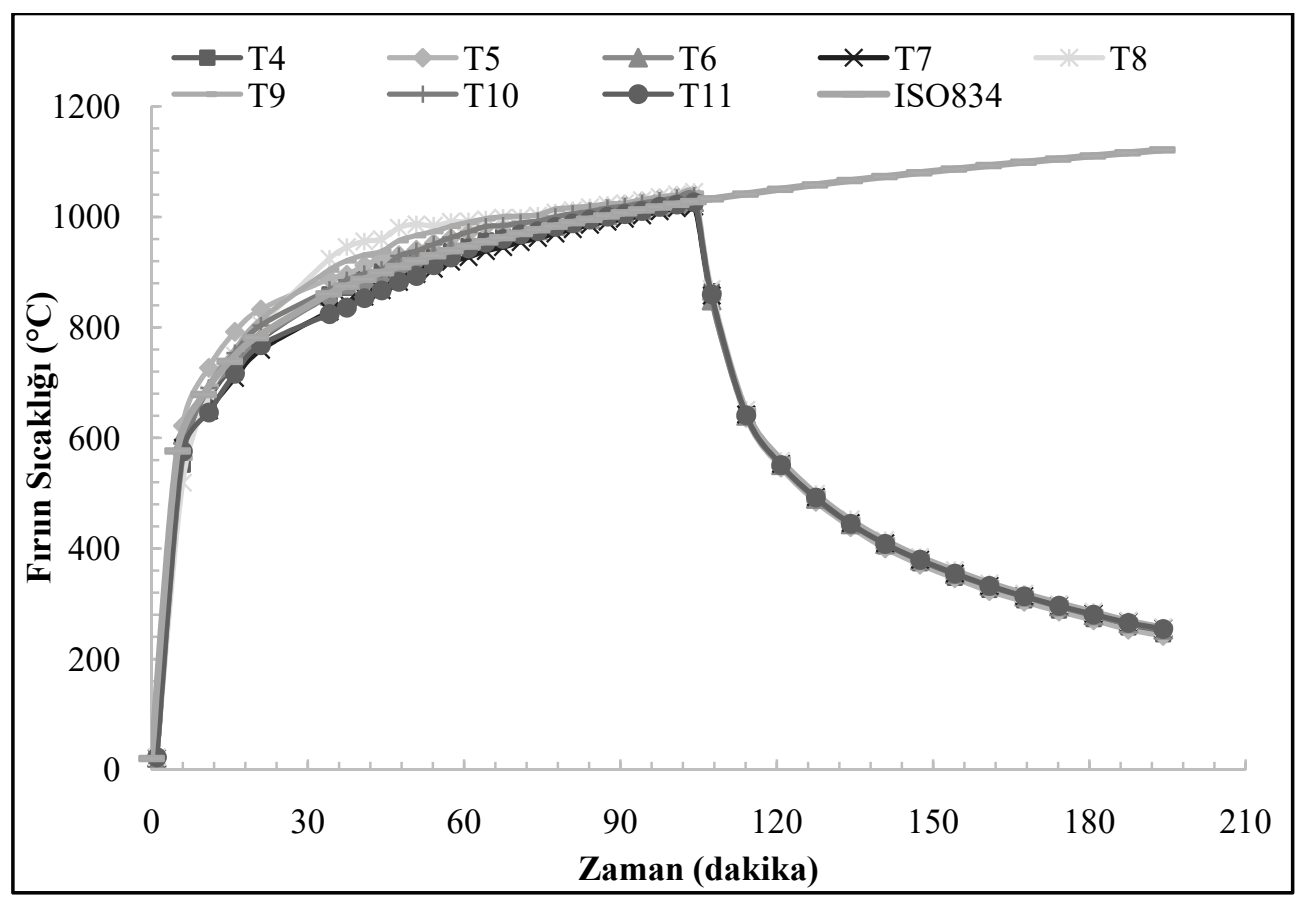

Şekil 8. Firınin farklı bölgelerindeki sıcaklık verileri (bkz. Şekil 5).

\section{2. Çelik kiriş ve Beton Döşemedeki Donatı Sıcaklıkları}

ISO834 yangın eğrisine maruz bırakılan kompozit döşeme bileşenlerinin sıcaklıkları, farklı bölgelerdeki 1sıl-çiftler aracıllğı ile ölçülmüştür (Şekil 9). TC10 1sıl-çifti deney başından itibaren hata vermiş ve 5. dakikada devre dışı kalmıştır. Alınan sonuçlara göre, korunmasız ikincil kiriş (IPE330) orta bölgesinde yer alan ve alt yüzeyden üste doğru sıralanan TC21,TC20 ve TC19 numaralı 1s1-çiftler beklenen doğrultuda ISO834 yangın eğrisine yakın davranış göstermişlerdir. İkincil kiriş orta bölgesinin alt yüzeydeki ısıl-çift (TC21), TC19'dan yaklaşık $100{ }^{\circ} \mathrm{C}$ daha fazla 1sınmıştır. İkincil kiriş yalıtımsız bırakıldığı için kirişin alt ve üst yüzeyindeki sıcaklık farkı oldukça azdır. İkincil kiriş ve birincil kiriş (HEA400) bağlantısı seramik yünü ile kaplanmıştır. Bağlantının yakınındaki kiriş bölgesinde yer alan ve alttan üste doğru sıralanan TC18, TC17, TC16 ve TC15 1sıl-çiftleri beklenen doğrultuda oldukça düşük bir sıcaklığa maruz kalmışlardır. İkincil kiriş ve birincil kiriş bağlantı bölgesinin alt ve üst yüzeyleri arasında yaklaşık olarak $100^{\circ} \mathrm{C}^{\prime}$ lik sıcaklık fark1 oluşmuştur. İkincil kiriş- birincil kiriş bağlantısı üzerinde yer alan 1sıl çiftlerden TC15 ve TC18, 1. ve 3. bulona, TC16 ve TC17 ise bağlantı plakası üzerine sabitlenmiştir. Bulon üzerine sabitlenmiş olan TC18 1sıl çifti TC15-17'den daha fazla sıcaklığa sahip olması bağlantının alt yüzeyinde yalıtımın tam anlamıyla sağlanamadığını göstermektedir. 
TC24, TC23 ve TC22 1sıl çiftleri simetrik koşulu sağlayan lineer rulman sistemine yakın yerde ikincil kiriş üzerinde olacak şekilde sırasıyla alt yüzeyden üste doğru yerleştirilmiştir. Lineer rulman sistemi, yangından etkilenmemesi için yalıtılmıştır ancak kiriş üzerindeki TC23 ve TC24 ısıl-çiftleri yalıtımın dışında bırakılmıştır. TC22 1 sıl çifti ise yalıtımın içinde kalmak zorunda kalmış ve Şekil 9'da görüldüğü üzere lineer rulman sistemi bölgesinde bulunan diğer isıl çiftlerden ayrışmıştır.

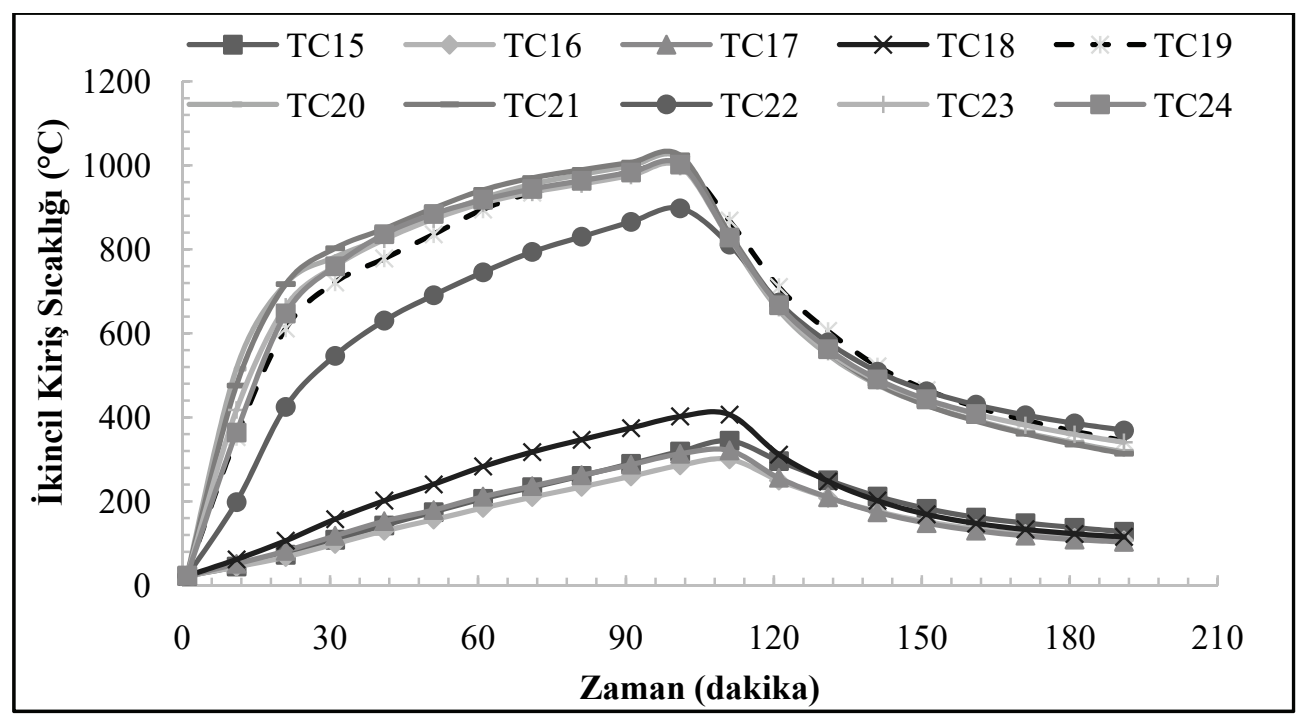

Şekil 9. Çelik kiriş üzerindeki ısıl-çift sıcaklıkları (bkz. Şekil 5).

Şekil 5'de yer haritası gösterilmiş olan beton donatısında yer alan ısıl-çiftlere ait sıcaklıklar Şekil 10'da gösterilmiştir. TC3 1 sıl çifti döşemenin montajı sırasında hasar görmüştür ve bu 1sıl çift üzerinden ölçüm yapılamamıştır. Ayrıca TC12 ssıl çifti 135 dakikadan sonra hasar görmüştür, dolayısıyla bu 1sıl-çiftten 135. dakika sonrası veri alınamamıştır. Döşemedeki donatıda değişik noktalarda yer alan ssıl çiftlerden elde edilen sıcaklık verileri $300{ }^{\circ} \mathrm{C}$ 'ye kadar farklılık göstermektedir. Bu sıcaklık farkının bir nedeni sac trapezin kalın $(120 \mathrm{~mm})$ ve ince $(70 \mathrm{~mm})$ olduğu bölgelerde bulunan ssıl-çiftlerin yangın ile arasında $50 \mathrm{~mm}$ beton yalıtımı farkı olmasıdır. Diğer bir nedeni ise firın duvarına yakın bölgelerin daha az sıcaklığa sahip olmasıdır. Fırının orta bölgesinde bulunan 1sıl çiftler (TC7, TC8, TC9, TC11) 500-600 ${ }^{\circ} \mathrm{C}^{\prime}$ ye kadar ısınırken, fırın duvarlarına yakın bölgelerde bulunan ısıl-çiftler $300{ }^{\circ} \mathrm{C}$ 'ye kadar ısınmışlardır.

Eurocode standartlarına göre ikincil kirişin (IPE330) yük taşıma özelliğini yitirdiği kritik sıcaklık $635^{\circ} \mathrm{C}^{\prime}$ dir [22]. Şekil 9'da görüldüğü üzere, kirişin sıcaklığı 20. dakikadan itibaren $635^{\circ} \mathrm{C}$ 'yi aşmıştır ve dolayısıyla döşeme sistem üzerinde ölü yük olarak asılı kalmıştır. Düşey statik yükleme sadece beton döşeme tarafından taşınmıştır. Mafsallı çelik bağlantı yalıtıldığ 1 için yangın esnasında $400^{\circ} \mathrm{C}$ altında kalmış ve Eurocode standartlarına göre kuvvet aktarım kapasitesini korumuştur [22]. 


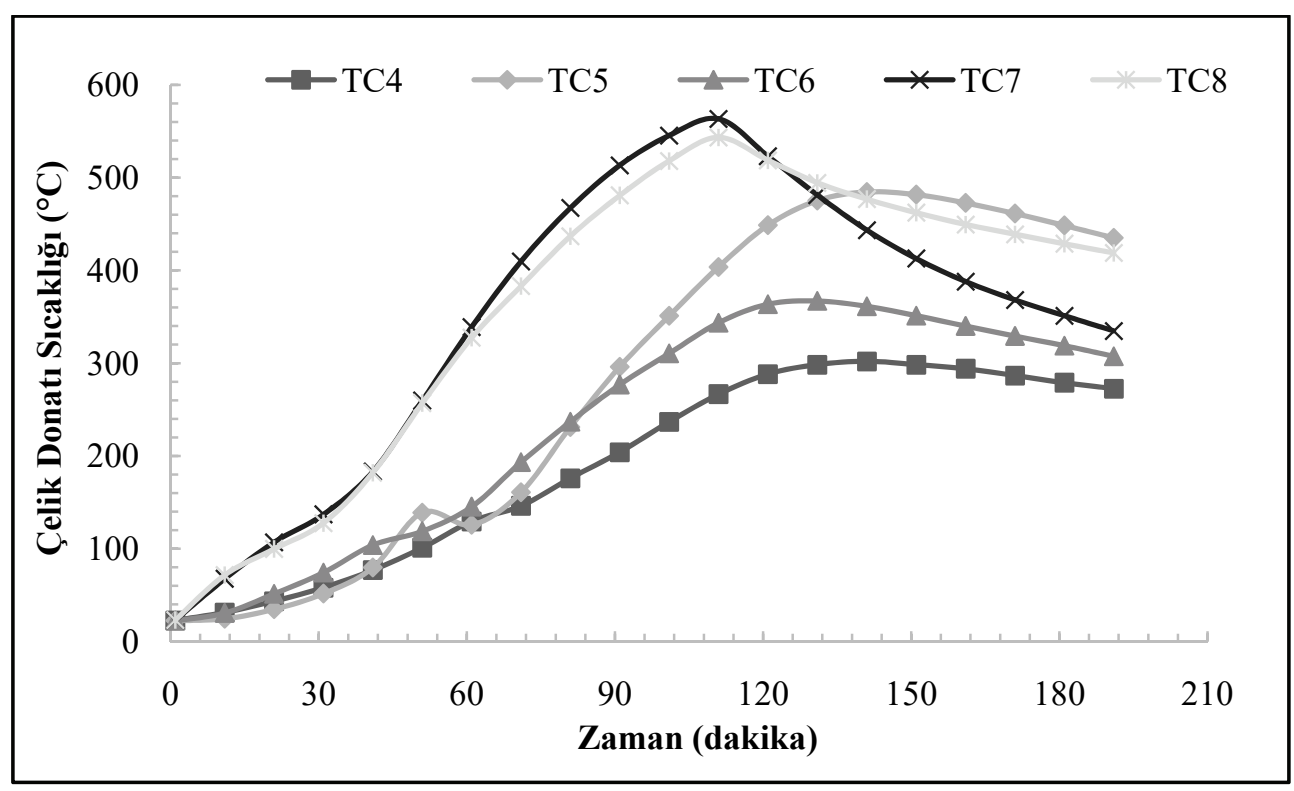

Şekil 10.Beton döşemedeki donatı üzerindeki ısıl-çift sıcaklıkları (bkz. Şekil 5).

\subsection{Döşemedeki Sehim Göstergeleri}

Beton döşeme üzerine Şekil 7'de gösterilmiş olan düşey statik yükleme yapıldıktan sonra kompozit döşeme simetrik kenar köşe noktasında 45 mm'lik deplasman kaydedilmiştir. Şekil 11'deki sehim ölçümleri düşey statik yükleme tamamlandıktan sonra betonun üst yüzeyine çakılan çivilere takılan cihazlar ile kaydedilmiştir. Şekil 11'de negatif (-) değerler statik yüklemeden gelen yer değiștirme (sehim) sıfirlandıktan sonra aşağı yönde yer değiştirmeyi ifade etmektedir. Şekil 11'de görüldüğü üzere yangın duvarı üzerindeki çevre kirişlerin etrafındaki noktalar beklenen doğrultuda çok az hareket etmişken, simetrik sınıra yakın, özellikle de köşe noktadaki bölge (D12) $50 \mathrm{~mm}$ kadar aşağı doğru sehim vermiştir. Dolayısıyla, statik yükleme ile beraber simetrik köşe (D12) toplamda $50+45=95 \mathrm{~mm}$ sehim vermiş̧tir. Diğer noktalardaki sehimler beklendiği gibi simetrik sınıra yaklaşırken kademeli olarak artmıştır. D1-D5 ana kirişe yakın oldukları için az sehim göstermişlerdir. Bunlardan D3, ikincil kirişin üzerinde olduğundan $20 \mathrm{~mm}$ kadar sehim verebilmiştir. 15. Dakikada tüm ölçerlerde hızlı bir aşağı inme eğilimi vardır, bunun nedeni ikincil kiriş (IPE330) sıcaklığının ortalama $800^{\circ} \mathrm{C}$ 'ye çıkması ve kirişin taşıma kapasitesini kaybetmesidir.

İkincil kiriş üzerindeki D11 en fazla $40 \mathrm{~mm}$ sehim göstermiştir. Bu veri, Eurocode standartlarına göre kompozit kirişlerde işletilebilirlik ('serviceability') $L / 250$ değerini aşmaktadır [21].

Sıcaklıklar arttıkça, sehimlerde yukarı doğru bir eğilim görülmüştür. Hızlı bir yükseliş ise 60. dakikada D12 ve D10'da gözükmektedir. Sicaklık artarken betonun yukarı çıkabilmesi fiziksel olarak ihtimal dışı olduğundan, bu esnada betona tutturulan çivilerin 60. dakikadan sonra beton üzerindeki çatlak ve kabarmalardan dolayı yerlerinden çıkıp gevşemeleri ve 
Çelik-Beton Kompozit Kat Döşemesi Yangın Dayanım Deneyi

dolayısıyla hatalı bir okuma gerçekleştirmeleri muhtemeldir. D9 noktasındaki oldukça fazla yukarı yönde $(+)$ hareket tam olarak açıklanamamaktadır.

Genel olarak, döşeme beklenenden daha az sehim göstermiştir. Bunun bir nedeni ölçümden kaynaklanan hatalar olabilir. Diğer bir nedeni ise simetrik birleşim mekanizmasında yangın esnasında oluşan sıcaklık artışı sonucunda genleşmelerin yaşanması ve döşemede oluşan eksenel kuvvetler sonucunda simetrik birleșim mekanizması birleșenleri arasında sürtünme kuvvetlerinin ortaya çıkmış olması olarak yorumlanabilir. Bu sürtünme kuvvetlerinin oluşması birleşim mekanizmasının doğru işleyişinin bir sonucudur. Sürtünme katsayısını azaltacak yağ vb. maddelerin kullanımı yangın deneyinde mümkün değildir. Bu araştırma kapsamında yapılacak yeni deneylerde sürtünme kuvvetlerinin etkisini azaltmak için hidrolik bir yükleme yapılacak ve bu şekilde döşeme üstündeki yük yangın süresince kademeli olarak arttırılacaktır.

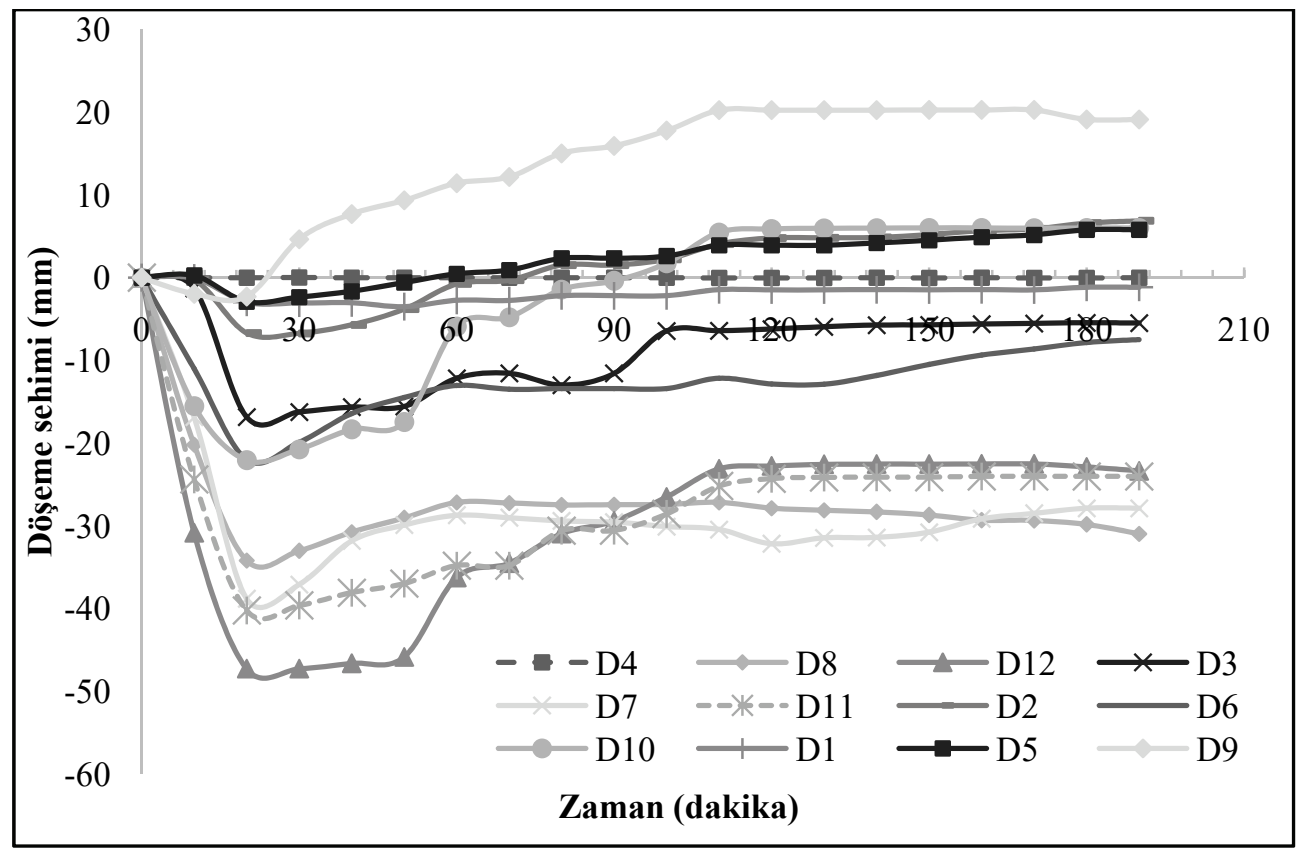

Şekil 11. Statik yükleme sonrasında, yangın esnasında beton döşeme üstünden ölçülen farklı noktalardaki sehimler (bkz. Şekil 6)

\subsection{Yangın Testi Öncesi ve Sonrası Gözlemleri}

Kompozit döşeme simetrik sınır koşullarını sağlayan birleşim mekanizmasının yüksek sıcaklıklarda doğru olarak çalıştığı teyit edilmiştir. Şekil 12'de görüldüğü üzere deney sonrasında ikincil kiriş (IPE330) kararlılığını (stabilite) yitirmemiş, kesme bağlantısı (bkz. Şekil 3) yakınlarında IPE330 alt bölgesinde yerel burkulmaya rastlanmıştır. 

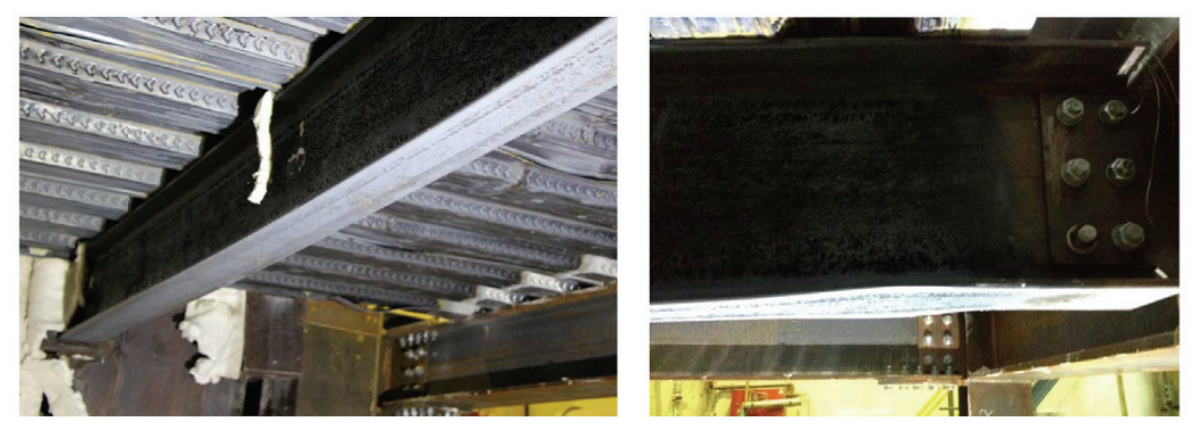

Şekil 12. Yalttımsı IPE330 kirişinin ve sac trapezin test sonrası deformasyonu IPE330 kirişindeki bağlantı yakınındaki yerel burkulma

Şekil 13a-b'de kompozit döșemenin test sonrası görüntüsü yer almaktadır. Simetrik kenarlara doğru artan sehim, döşemede çekme bölgesi oluşturmuş beton yüzeyinde çatlaklar meydana gelmiştir. Bu durum beton döşemenin membran etkisine girdiğini açıkça göstermektedir (bkz. Şekil 13c).

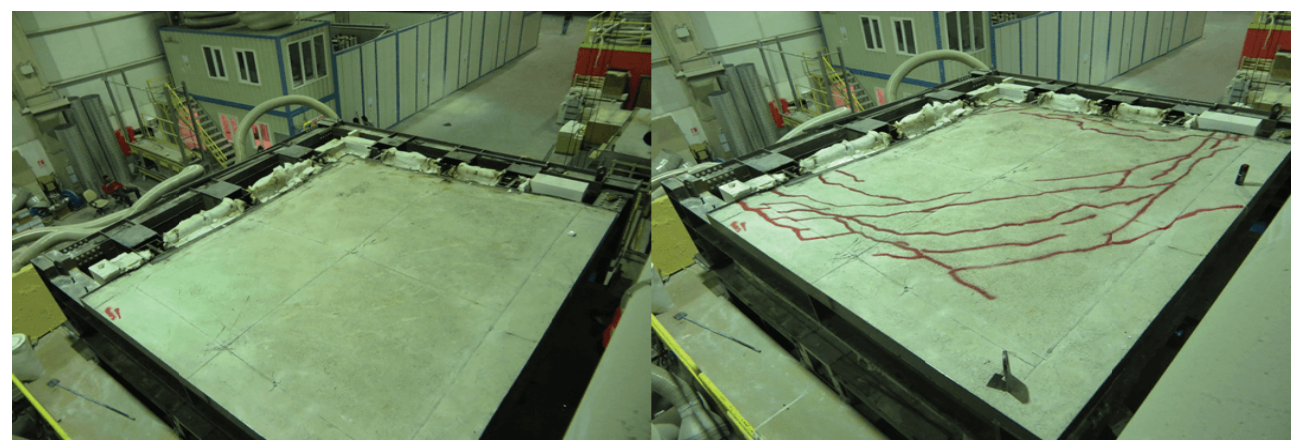

(a)

(b)

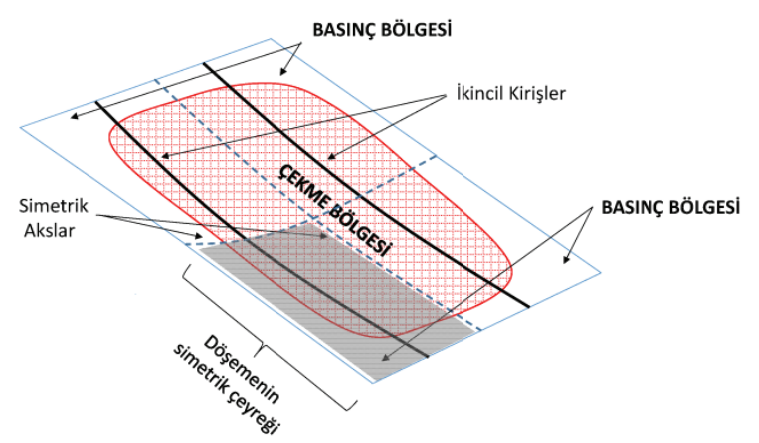

(c)

Şekil 13. (a) Kompozit döşemenin test sonrasındaki görüntüsü, (b) çatlakların kırmızı boya ile belirginleştirilmiş hali, (c) döşemenin yangın esnasindaki membran davranışı tasviri 


\section{SONUÇLAR VE ÖNERILER}

Bu çalışmada, Türkiye'de araştırma odaklı ilk çelik-beton kompozit kat döşemesi yapısal yangın deneyi gerçekleştirilmiştir. Bu çalışma, Türkiye'de gerek yangın yönetmelikleri açısından gerekse yapısal yangın konusunda teorik, nümerik ve deneysel araştırmalardaki eksiklikleri gidermeyi amaçlamıştır.

Kompozit döşemenin standart yangın eğrisine göre 105 dakika yangın dayanımı olduğu kanıtlanmıştır. Alınan sonuçlar, yalıtımsız bırakılmış olan ikincil kirişin (IPE330) $800{ }^{\circ} \mathrm{C}$ e kadar ısındığını ve dayanımını yitirdiğini göstermektedir. Ancak beton döşemenin membran davranışı göstererek yük taşıyıcı özelliğini yangın boyunca devam ettirdiği gözlemlenmiştir. Dolayısıyla kompozit kat döşemelerinde taşıyıcı özelliğini yangın esnasında yitirecek olan ikincil çelik kirişlerin yalıtımsız bırakılması önerilmektedir. Büyük çaplı çelik yapılarda, sabit ve hareketli yük dağılımını sağlayan ikincil kirişlerin yalıtılmamasının yangına karşı yalıtım maliyetini $15-20 \%$ civarında azaltacağı öngörülmektedir. $\mathrm{Bu}$ öneri ulusal ve uluslararası ekonomik kazanımlara ve inşaat sektöründe karbon ayak izinin azaltılmasına olanak sağlayacaktır.

Bununla birlikte kompozit döşemede yer alan donatıların da sıcaklıkları kompozit döşeme merkezi çevresinde $400{ }^{\circ} \mathrm{C}$ 'e kadar ulaşmıştır. Çelik (hasır) donatıların betonun alt yüzeyinden uzak yerleştirilmesi ve böylece yangına karşı beton tarafından yalıtılması önerilmektedir. Donatının basınç bölgesine yakın yerleştirilmesi, geleneksel tasarımın karşıtı bir çözümdür. Döşemenin membran davranışını gerçekleştirmesi ancak içindeki donatıların sünek ve yüksek mukavemete sahip olmasına bağlıdır.

Yapısal yangın deneyinde ilk defa kullanılan simetrik sınır koşulları oluşturan bir birleşim mekanizması kullanılmıştır. Bu mekanizma yangın esnasında moment aktaran, yatay düzlemde sabit hem çekme hem de basınca karşı dayanıklı, düşey düzlemde serbest olacak şekilde tasarlanmıştır. Bu proje aşamasında ortaya çıkan buluş için Türk Patent Ofisine başvuru yapılmıştır. Birleşim mekanizmasının yangın esnasında oluşan yüksek sıcaklıklar altında beklendiği şekilde düşey serbestlik sağladığı, sehim ölçerlerden alınan veriler ile doğrulanmıştır.

\section{Teşekkür}

Bu araştırma Boğaziçi Üniversitesi Bilimsel Araştırma (BAP) No. 7122P, TÜBİTAK 3001 Başlangıç Ar-Ge No. 114M791 ve Avrupa 7. Çerçeve Marie Curie IIF CONFIRE 328993 proje destekleri ile gerçekleştirilmiştir. Kompozit döşemenin çelik çerçeve ve birleşim mekanizması imalatında emeği geçen Çeçen İnşaat ve Enerji Sistemleri A.Ş.'den Cengizhan Çeçen ve RZK Çelik A.Ş.'den Kağan Yemez'e teşekkür ederiz. Deney sırasında proje asistanlığı yapmış Boğaziçi Üniversitesi’nde yüksek lisansını devam ettiren Caner Bölükbaş'a yardımlarından dolayı teşekkür ederiz.

\section{Kaynaklar}

[1] Gann, RG. Final report on the collapse of World Trade Center Building 7, Federal building and fire safety investigation of the World Trade Center disaster, NCSTAR1A, NIST, 2008. 
[2] The Geneva Association, World Fire Statistics Newsletter, 29, 2014.

[3] Beitel J and Iwankiw N., Analysis of needs and existing capabilities for full-scale fire resistance testing, National Institute of Standards and Technology, NIST GCR, 02$843,2002$.

[4] British Steel plc, Swinden Technology Centre U. The behaviour of multi-storey steel framed buildings in fire, Technical report, British Research Establishment (BRE), UK, 1999.

[5] Bailey CG., The structural behaviour of steel frames with composite floor slabs subject to fire: Part 1: Theory, The Structural Engineer, 78(11), 19-27, 2000.

[6] Bailey CG., Membrane action of slab/beam composite floor systems in fire, Engineering Structures, 26, 1691-1703, 2004.

[7] Bailey CG. and Toh WS., Small-scale concrete slab tests at ambient and elevated temperatures, Engineering Structures, 29, 2775-2791, 2007.

[8] Buchanan Andrew H., Structural Design for Fire Safety, New York, Wiley, 2001.

[9] Wald F, da Silva LS, Moore D, Lennon T, Chladna M, Santiago A, Benes M, and Borges L., Experimental behaviour of a steel structure under natural fire, Fire Safety Journal, 41(7), 509-522, 2006.

[10] Astaneh-Asl A, Liu J, McMullin KM., Behavior and design of single plate shear connections, Journal of Constructional Steel Research, 58(5-8), 1121-41, 2002.

[11] Garlock ME and Selamet S., Modeling and behavior of steel plate connections subject to various fire scenarios, Journal of Structural Engineering, ASCE, USA, 136(7), 897-906, 2010

[12] Selamet S, Garlock ME., Robust fire design of single plate shear connections. Engineering Structures, 32(8), 2367-2378, 2010.

[13] Chung KF and Ip KH., Finite element investigation on the structural behaviour of cold-formed steel bolted connections, Engineering Structures, 23(9), 1115-25, 2001.

[14] El-Rimawi JA, Burgess IW, Plank RJ., The influence of connection stiffness on the behaviour of steel beams in fire, Journal of Constructional Steel Research, 43(1-3), 1997.

[15] Selamet S, Garlock ME., Predicting the maximum compressive beam axial force during fire considering local buckling, Journal of Constructional Steel Research, 71, 189-201, 2012.

[16] Selamet S, Garlock ME., Plate buckling strength of steel wide-flange sections at elevated temperatures. Journal of Structural Engineering, ASCE 2013; 139(11): 18531865 .

[17] Selamet S, Bolukbas C., Fire resilience of shear connections in a composite floor: Numerical investigation, Fire Safety Journal, doi:10.1016/j.firesaf.2016.02.003, 2016. 
Çelik-Beton Kompozit Kat Döşemesi Yangın Dayanım Deneyi

[18] Kirby BR., The behaviour of high-strength Grade 8.8 bolts in fire, Journal of Constructional Steel Research, 33(1-2): 3-38, 1995.

[19] Binaların yangından korunması hakkında yönetmelik, Resmi Gazete, Sayı 27344, 2009.

[20] "Simetrik sınır koşulları sağlayan bir yangın dayanım test mekanizması", Evrak tarihi: 26.11.2015, Evrak No: 2015-GE-436248, Dosya No: 2015/14992

[21] CEN. ENV 1991-1-2:2002 - Eurocode 1, Actions on structures, Part 1.2: General actions - Actions on structures exposed to fire, Brussels, 2002.

[22] CEN. ENV 1993-1-2:2005 - Eurocode 3, Design of steel structures, Part 1.2: General rules - Structural fire design, Brussels, 2005. 